\title{
Assessment of the Socioeconomic Aspects of Street Vendors in Dhaka City: Evidence from Bangladesh
}

\author{
Shaiara Husain ${ }^{1}$, Shanjida Yasmin ${ }^{1} \&$ MD. Shahidul Islam ${ }^{1}$ \\ ${ }^{1}$ Department of Economics, Southeast University, Dhaka, Bangladesh \\ Correspondence: Shaiara Husain, Department of Economics, Southeast University, Dhaka, Bangladesh. E-mail: \\ shuma153@yahoo.com
}

Received: June 15, 2015 Accepted: August 3, 2015 Online Published: August 28, 2015

doi:10.5539/ass.v11n26p1 URL: http://dx.doi.org/10.5539/ass.v11n26p1

\begin{abstract}
In Bangladesh, informal sector plays a prominent role in terms of their contribution to employment generation and poverty alleviation. Street trading constitutes a significant part of this sector involving street vendors as the key players. Nonetheless the roles of the vendors are ignored and their vulnerable condition is never emphasized. This paper tries to investigate the present status of different street vendors in Dhaka City with the aim of assessing the socio-economic conditions and business issues conducting a field survey of vendors engaged in fruit, vegetable, tea and other food items selling through in-depth personal interview using 3-Stage sampling method. This Study indicates that poverty, migration from rural area, low education, exorbitant supply of labor and large family size are the major driving forces of carrying out this business. According to this survey, Personal savings is the single most important source of financing the vending business. Selling assets and lending from cooperative society are the two other major sources of financing the business representing the absence of formal credit facilities for these poor street vendors. This article also reveals the importance of social capital in street vending and the excessive work hour of the vendors and lack of opportunities of alternative formal employment evident from their fulltime working status even in the presence of political instability, natural calamity or financial crisis.
\end{abstract}

Keywords: street vendor, informal sector, personal savings, socio-demographic profile, social capital

\section{Introduction}

In Dhaka, like any other megacities of south Asia and Africa, street trading is most prevalent phenomenon. A cursory view of Dhaka city with overwhelming number of street vendors demonstrates the role of this activity as a sponge that absorbs exorbitant number of surplus labor. It is reported unofficially by several hawaker association that around 2.5 lakh street vendors ply their business on the capital cities' public sidewalks in recent years which has increased from 90,000 in 2005 resulting an emergence of new avenue for urban poor to support themselves and their families. As a consequence of rapid urbanization, inadequate opportunities of formal work place and perpetually increasing population of Dhaka city, compels unskilled people to engage themselves in street trading which entails small capital to start and there is low barriers to entry and flexible work hour. In Dhaka, these vendors run their business under inhospitable conditions, without basic facilities coupled with the fear of harassment and damage to their goods. Notwithstanding, street vendors are noticeable in all over the Dhaka city, the main hub of these vendors are prevalent in Motijheel, Baitul Mukarram, Gulistan, Shahbagh and New Market Areas. Vendors are exposed to political unrest and extortionists. Their business are at stake due to frequent eviction from their workplace, therefore, the vendors of new market reported that they have to pay 200 taka a month to a gang that shares that amount with law maker. In other areas such as Baitul Mukarram, GPO and Purana Paltan vendors pay the police Tk 5 daily to avoid harassment. Street vendors of Bangladesh were more vulnerable than those in the neighboring countries due to poverty, lack of space for vending and lack of awareness about their rights (Bhowmik, 2005). They are also deprived of institutional credit facilities that could help them increase their income. Street trading has been creating employment opportunities for the urban unskilled poor and migrated rural poor workers together with expanding the market for cheap products contributing to poverty alleviation. Despite of this contribution to the economy, street trading is causing inconvenience to the pedestrians and vehicle to ply on the street due to haphazard settlement of these vendors. The main problem resulting from increasing street vending is the overcrowding and it leads to encroachment of 
the public places and roads. Congestion and pollution of city environment in terms of garbage are also linked with this. In this connection, problems relating to theft, hoodlum, pick pocketing, crime are linked with increasing street vending activities.

Therefore, street trading in Dhaka city is treated as illegal activity and vendors are swept away by the lawmaker wherever they are found. This uncertain eviction of the business coupled with the limited access to capital, inadequate local infrastructure and harassment by the local authorities set a negative impact on their business.

\section{Objective of the Study}

The specific objectives of this study are to examine street vendors' income levels, access to finance, working hours as well as working status, level of education and impact of social capital.

\section{Background of the Study}

Street trading is a growing urban phenomenon in Dhaka city, visible at different places in stationary or moving form. Hence, they are defined as traders who sell goods to the public without a permanent premise to conduct business (Bhowmik, 2005). Those self employed workers in the informal sector recognized as street traders who do not have a fixed, permanent concrete arrangement to sell their goods and services (Shaha, 2011).

They are the most vulnerable and marginalized fragment of urban poor. Despite, they play a dynamic role to meet the demand of urban dwellers in Dhaka, providing cost effective and durable items together with generating income and employment opportunities for large number of inhabitants resulting an important earning source of their families (Suraiya \& Noor, 2012). Not only in Bangladesh, in kathmandu, Nepal, street vending rendered as a prominent source of earning livelihood for rural people in urban area along with serving urban poor providing goods in cheaper price (Timalsina, 2011; Adhikari, 2011). In addition to these benefits, it strengthens the economy by providing products to the markets that are produced in small and large scale industries. Street vending plays a vital role in economic development contributing in reducing poverty, generating employment and increasing social mobility. (Nirathron, 2006; Njaya, 2014). Alternatively, street trade considered as a feasible livelihood due to its small start up cost, flexible working hours and low barrier to entry (ILO \& Wiego, 2013).

Considering the employment context, many street vendors work long hours at the same site on daily basis while other vendors move to two or more sites to grab the opportunity to sell to different types of customers. Some of them carry out this occupation as a primary source of income, others as part time, keeping open an opportunity to earn extra income. A variety of employment statuses can be found among street vendors as well. Most vendors work as independent self-employed entrepreneurs, either with or without employees. There are also many vendors who work for helping family members, and some work as employees of informal or even formal enterprises (Andringa \& Kies, 1989).

In Southeast Asia, the average earnings of a vendor may be three to ten times more than the minimum wage and they are often comparable to the wages of skilled laborers' employed in the formal sector (Andringa \& Kies, 1989). Through regression analysis, it has been found that business experience, and initial capital is two key factors that positively affect sales revenue of street trader in Dhaka city. Formal education, however, does not have any significant impact on business performance. Lack of security and problems in the supply of raw materials are two major problems as perceived by the vendors (Muzaffar, Huq, \& Mallik, 2009). Most of the street vendors are unskilled and low-educated. In Dhaka, majority of the traders completed their secondary level of education (Suraiya \& Noor, 2012) where as in Mumbai and Tamil Nadu in India, the average year of schooling of the vendors are below primary years of schooling. (Shaha, 2011; Karthikeyan \& Mangaleswaran, 2013)

The number of women street vendors is increasing in Dhaka city. This is because women who do not have any other way to meet the subsistence needs of their families enter into the informal sector like street vending. But street vending is a non-traditional and male-dominated job and there is an earning gap between men and women vendors (Khanam, 2006). In West Africa women entrepreneurship is dominant in the informal sector, and women entrepreneurs engaged in the cowpea street food sector can earn incomes 4 times to 16 times higher than the minimum legal wage in Niamey and Kumasi, respectively. Incomes earned from these entrepreneurial activities contribute directly to health, education and needs of their families (Otoo, Fulton, Ibro, \& Lowenberg-DeBoer, 2009). Furthermore, in Cambodia and Mongolia, street trading treated as a viable choice for poor entrepreneurial women and those who are excluded from formal employment to support their families. In Africa, this sector is mainly dominated by female (Nirathron, 2006; ILO \& Wiego, 2013). Majority of the female vendors of Kokhrajhar district in India aged between 40 to 50, married and income earned between 4000 to 8000 indian rupees, more likely to be exposed to health hazard (Basumatary, 2013). 
The main problems that the street vendors faced both during their start-up and operation of their activities were lack of working places, harassments and eviction from selling place by police and private shop guardians, lack of market, non-profitability of the business, lack of credit, lack of freedom and social security during operation of their business and cleanness of their working environment. Moreover, they have to borrow money from moneylender at a high interest rate for their economic activity and social security, bribing the legal authorities. Long working hour and unsecured work place coupled with excessive rent seeking by local authorities result indecent working environment for street vendors (Shaha, 2011). Street trading involve small earning, high risk, especially for the fresh vegetable and fruit seller and regular occupational and physical hazard as a result of unhygienic market condition. They also indentified that the street vendors are highly exposed to economic downturn and political unrest (ILO \& Weigo, 2013).

Notwithstanding, street vendors plays a dynamic role in economic development, they are also liable for some unfavorable visible effects such as lack of formalization and weak management system, which create problems in urban areas by producing street garbage and gathering crowd on the footpath in Dhaka (Suraiya \& Noor, 2012). Issues relating to urban management and controlling over the deteriorating city environment due to increase vending activities are, of course, challenging for urban governance. Therefore, there are confrontations between authorities and vendors over licensing, taxation, encroachment of public places and pavements and on increasing social problems in Kathmandu Metropolitan City (Timalsina, 2011).

In this section the background of the study is being illustrated. The paper then continues with a discussion of methodology and sampling used to conduct the research and then goes on explaining the socio-demographic and economic characteristics of the street vendors from the primary data obtained from the questionnaire including both closed and open ended questions formulated and developed by the authors. The paper moves forward with illustrating various types of problems faced by the street vendors. Finally, the study concluded with policy implications.

\section{Conceptual Framework}

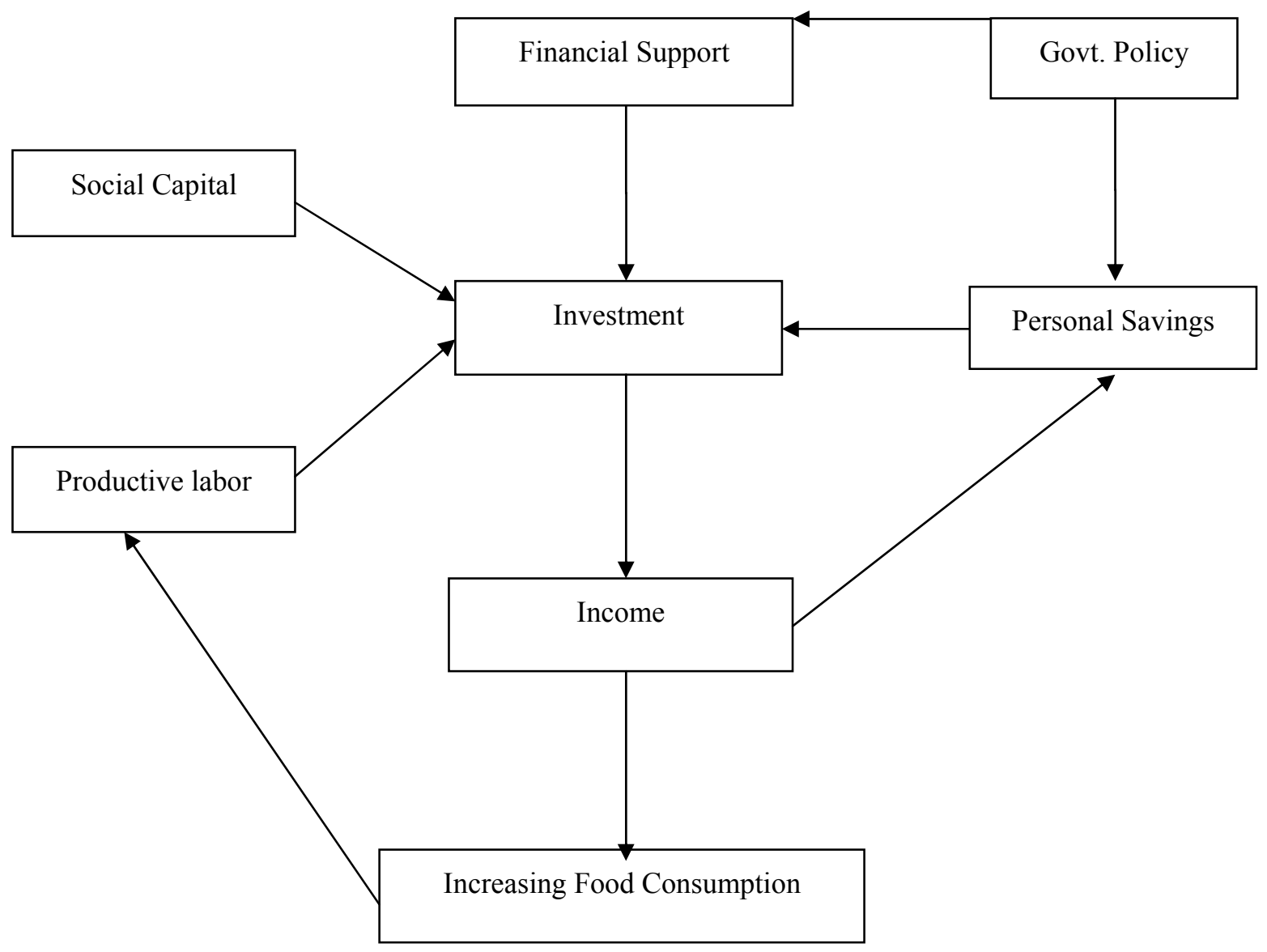

Figure 1. Conceptual Framework for Improvement of the livelihood of Street Vendors

Adopted and modified from Mahmud et al. (2014) 


\section{Research Methods}

The component or unit of analysis of the present study are the individual street vendor in Dhaka metropolitan city. Static vendors, who have a specific space for their activity (though the space is not officially recognized by the government) are participants in the present research. Dhaka has been selected according to its rapid urbanization, massive commercialization, geographical location and other certain characteristics such as employment status and wide spread formal retail chain and street trading among all major cities in Dhaka. The city of Dhaka was also selected because of its diversity in terms of economic activities as well. A survey for the study was conducted from March 2015 to May 2015. A structured questionnaire with closed and open-ended questions is used in accordance of the objective of the study exploring the current situations of street vendors. Personal interviews with 136 individual street vendors were conducted. These one to one correspondences helped in achieving an understanding of the common issues.

\subsection{Sampling}

Since the present research paper is mainly primary data based, three stage (3-Stage) sampling method has been designed to draw sample. In the first stage, When population is scattered over the region and complete lists of the total population is not available, 'cluster' helps to obtain easily for sampling (Murthy, 1967). In 1st Stage Unit, Dhaka has been divided into nine parts (Cluster), such as, Farmgate, Panthapath, Khathalbagan, Kafrul, Mirpur, Mohakhali, Jatrabari, Gazipur and Banani in terms of volume of street vendors due to unavailable list of street vendors in Dhaka. These clusters are selected at random by using geographical map of Dhaka city. Since street vending profession is heterogeneous in nature, stratification method helps to make homogeneous group in that group of workers. In each cluster, street vendors have been divided into tweleve 'stratum' such as vegetables vendors, fruits vendors and cigarettes, tea, tobacco leaf (pan), chocolates, chewing-gum, lozences, cakes, breads, biscuits and banana. According to the heterogeneous number of street vendors in each part, 'quota' has been fixed to draw sample from each stratum since population was unknown (Ahuja, 2011). This quota depends on the volume of street vendors of each part and street vendors have been selected at random within each 'quota' from each 'cluster'. This study covers 136 samples from the eight places in Dhaka Metropoliton city.

5.

\subsection{Demographic and Social Profile}

Table 1. Socio-demographic profile

\begin{tabular}{|c|c|c|c|c|}
\hline Indicators & & Tea Stall Vendor $(\%)$ & Vegetable Vendor (\%) & Fruit Vendor (\%) \\
\hline \multirow[t]{4}{*}{ Age } & $15-25$ & $4(7.84)$ & $16(32.65)$ & $3(8.33)$ \\
\hline & $26-35$ & $27(52.94)$ & $26(53.06$ & $16(44.44)$ \\
\hline & $36-45$ & $17(33.33)$ & $5(10.2)$ & $14(38.89)$ \\
\hline & $45-60$ & $3(5.88)$ & $2(4.08)$ & $3(8.33)$ \\
\hline \multirow[t]{3}{*}{ Marital Status } & Married & $43(84.31)$ & $38(77.55)$ & $36(100)$ \\
\hline & Unmarried & $6(11.76)$ & $11(22.45)$ & 0 \\
\hline & Separated & $2(3.92)$ & 0 & 0 \\
\hline \multirow[t]{4}{*}{ Education } & No education & $4(11.43)$ & 0 & $2(7.69)$ \\
\hline & primary education & $12(34.29)$ & $17(40.48)$ & $6(23.08)$ \\
\hline & Secondary & $17(48.57)$ & $25(59.52)$ & $16(61.54)$ \\
\hline & Higher secondary & $2(5.71)$ & 0 & $2(7.69)$ \\
\hline \multirow[t]{5}{*}{ Family Size } & 2 to 4 & $18(35.29)$ & $24(51.06)$ & $18(50)$ \\
\hline & 4 to 6 & $26(50.98)$ & $21(44.68)$ & $8(22.22)$ \\
\hline & 6 to 8 & $4(7.84)$ & $1(2.13)$ & $7(19.44)$ \\
\hline & 8 to 10 & $2(3.92)$ & $1(2.13)$ & $3(8.33)$ \\
\hline & 10 to 12 & $1(1.96)$ & 0 & 0 \\
\hline \multirow[t]{3}{*}{ Number of earning members } & Only earning member & $30(78.95)$ & $29(59.18)$ & $19(55.88)$ \\
\hline & Working partner & $8(21.05)$ & $20(40.82)$ & $15(44.12)$ \\
\hline & Total & $51(100)$ & $49(100)$ & $36(100)$ \\
\hline
\end{tabular}

Note: Calculation is done by using data from authors' own survey of 2015

The informal sector in Dhaka city are highly diversified in nature. Vendors may get engaged in fixed location activities or mobile and semi-mobiles activities. Although street vending is undertaken by women and men of all 
ages, but the majority of the vendors are concentrated between the ages of 26-35. Around half of the vendors of tea stall (around 52.94\%), vegetable (around 53.06) and fruit (44.44\%) are aged 26 to 35, with the proportion declining after age 45 . By comparison, around $30 \%$ of vendors involved with tea and fruit selling while only $10 \%$ are engaged in vegetable selling within the age group 36 to 45 , indicating higher involvement of (32\%) of vegetable vendor of age 15 to 25 than other vendors. Moreover, this advocates that the economically active age group is participating in street trading reflecting the high unemployment levels in the country.

Street vending is a more important source of employment among married person than among unmarried and majority of them are only earning member. With respect to marital status, highest proportion of vendors of these above mentioned products are married, suggesting that married people carry out this occupation to support their families. In terms of family size, around $50 \%$ of the tea vendors belong to the group of 4-6 number of members in family while half of the respondents of vegetable and fruit sellers have 2 to 4 number of members in their family.

Considering the education level of vendors it is evident from the data (see Table 1), the low-educated people chose street vending as occupation. It is revealed from our study that around half of the tea stall, vegetable and fruit vendors (around 48\%, 59\% and 61\% respectively) have completed secondary education. Hence, they do not possess the education level to find highly paid, decent employment in the formal sector and force to join to the informal sector.

\subsection{Economic Profile}

The income of street vendors depends on the products they sell, and it varies from product to product, from location to location, and also in terms of the volume and terms of trade. The daily income of the street vendors is given in Table 2 in taka. It is evident that all type of vendors are poor as majority of the vendor's daily income is between 300 to 800 (around $35 \%$ for tea, vegetable and fruit vendors).

Table 2. Economic profile

\begin{tabular}{|c|c|c|c|c|}
\hline Indicators & Column 1 & Tea Stall Vendor $(\%)$ & Vegetable Vendor $(\%)$ & Fruit Vendor $(\%)$ \\
\hline \multirow[t]{6}{*}{ Income } & $300-800$ & $18(35.29)$ & $18(36.73)$ & $12(33.33)$ \\
\hline & $900-1400$ & $6(11.76)$ & $8(16.32)$ & $4(11.11)$ \\
\hline & $1500-1900$ & $8(15.68)$ & $7(14.28)$ & $9(25)$ \\
\hline & $2000-2400$ & $5(9.8)$ & $8(16.32)$ & $6(16.66)$ \\
\hline & $2500-2900$ & $3(5.8)$ & $2(4.08)$ & $2(5.5)$ \\
\hline & $3000-3500$ & $11(21.56)$ & $6(12.24)$ & $3(8.33)$ \\
\hline \multirow[t]{9}{*}{ Source of capital } & Own savings & $28(54.9)$ & $20(44.44)$ & $20(55.55)$ \\
\hline & Spouse savings & $4(7.84)$ & $3(667)$ & $3(8.33)$ \\
\hline & Selling asset & $5(9.8)$ & $6(13.33)$ & $4(11.11)$ \\
\hline & Money from in-laws & $4(7.84)$ & $1(2.22)$ & $2(5.56)$ \\
\hline & Borrowing from friends & $3(5.88)$ & $4(8.89)$ & 0 \\
\hline & Lending from Shomiti & $3(5.88)$ & $4(8.89)$ & $4(11.11)$ \\
\hline & Loan from merchant & & $2(4.44)$ & $3(8.33)$ \\
\hline & Loan from NGO & 0 & $4(8.89)$ & 0 \\
\hline & Others & $4(7.84)$ & $1(2.22)$ & 0 \\
\hline \multirow[t]{2}{*}{ Labour } & No Additional Labour & $30(58.82)$ & $20(39.22)$ & 39.22 \\
\hline & Additional Labour & $21(41.18)$ & $31(60.78)$ & 60.78 \\
\hline \multirow[t]{4}{*}{ Average working Hour } & 3 to 7 & $4(7.84)$ & 0 & 0 \\
\hline & 8 to 11 & $4(7.84)$ & $10(20.83)$ & $1(2.78)$ \\
\hline & 12 to 16 & $37(72.55)$ & $26(54.17)$ & $32(88.89)$ \\
\hline & 17 to 21 & $6(11.76)$ & $12(45)$ & $3(8.33)$ \\
\hline \multirow[t]{2}{*}{ Impact of Social Capital } & No & $16(31.37)$ & $14(28.57)$ & $8(22.22)$ \\
\hline & Yes & $35(68.63)$ & $35(71.43)$ & $28(77.78)$ \\
\hline \multirow[t]{2}{*}{ Work Status } & Full time & $43(86)$ & $37(84.09)$ & $31(86.11)$ \\
\hline & Part time & $7(14)$ & $7(15.91)$ & $5(13.89)$ \\
\hline Total & & $51(100)$ & $49(100)$ & $36(100)$ \\
\hline
\end{tabular}

Note: Calculation is done by using data from authors' own survey of 2015 
Though, $21 \%, 12 \%$ and $8 \%$ of tea, vegetable and fruit vendors respectively earn between 3000 to 3500 taka daily indicating discrepancy between income earning. The street vendors of tea \& others (tobacco leaf, chocolate, lozence, cigarette, bread, banana, chewing-gum, biscuit), fruit and vegetable vendors of Dhaka city manage their own source of capital from variety of sources (see Table 2). They get capital from either own savings, spouse savings, selling assets or can borrow money from in-laws, local cooperative society or shomity, friends or take loan from local money lender, merchant, NGO and other sources. We observe almost $55 \%$ of the tea vendors operates their business from own savings which is the major source of running business constituting more than half of the total respondents (See Table 2).

Savings of the spouse and money from in-laws are another important source of business fund implying that $7.84 \%$ of the tea and other street vendors run their business from these sources. $5.8 \%$ vendors take loan from friends and local cooperative society/shomity. Another important observation is that $9.8 \%$ people from the sample run the business from selling the assets, second most important source of funding which is an indication of transferring from other urban informal occupations and/ migrating from rural area of Bangladesh. (See table 2) Considering the case of vegetable vendors, own savings is the most important source of funding, implying $44 \%$ of the vendors manage funding from own savings. Selling assets constitutes $13.3 \%$ of the street vendors funding and $8.89 \%$ of vegetable vendors borrow from their friends, shomity and NGO. For fruit vendors own savings is the most important source of funding implying $55 \%$ of the street vendors set up their business from own savings. Other important sources include selling assets and borrowing money from shomity (11.11\%) and savings of the spouse and loan from merchants $(8.33 \%)$ are two other mention worthy source of business. Finally it can be concluded that own savings or equity participation is the most crucial factor for running street vending business. Two most other important sources of financing include selling assets and borrowing from local cooperative society or shomity.

It is found from this survey that the informal sector entrepreneurs may not confined only to oneself and family labor. They also employ wage earners if needed. In this connection it can be added that most of the vendors think hiring extra labor may increase their monthly income. Surprisingly $60.78 \%$ of the vegetable vendors and $60.78 \%$ of the fruit vendors think that extra labor would have significant positive effect on their income. However, 58 per cent of the respondents think that adding extra labor would not add to their income for tea $\&$ other vendors. We also tried to find out the opportunity cost of doing vending businesses. Most of the tea \& vendors answered that they wanted to give a stationary shop or fruit shop or vegetable shop or would have purchased land in rural area or remained satisfied with present state of affairs. The important observation to note is that most of them wanted to engage themselves in this street vending in either way possible due to their knowledge of profitability of this business and family tradition. A large number of the businesses are being run on a basis of single proprietorship followed by a very small segment of partnership.

An interesting fact is revealed regarding the effectiveness of social capital by considering the neighborhood, kinship, friendship, and known people in account on daily sale. Majority of the buyers of the vendors are regular customers including rickshaw \& car drivers, students of schools, colleges, people of the local area, tenants, businessmen and day laborers. Since majority of the customers are regular it can be inferred that neighborhood, friendship, kinship or social capital played a significant role in earning extra income which is being supported by our data. Vendors are reported to have given discount to their regular customers since social capital plays a major role in their business. The overwhelming proportion of the respondents reported about the efficacy of social capital (around $68.6 \% 71.4 \%$ and $77.7 \%$ of tea, vegetable and fruit vendors respectively). They have to rely exclusively on social networks for running their business.

It is evident from the data regarding average working hour on daily basis that $72.5 \%, 54.17 \%$ and $88.89 \%$ of the tea $\&$ others, vegetable and fruit vendors respectively work 12 to 16 hours respectively on average daily. $11.76 \%$, $45 \%$ and $8.3 \%$ of the tea $\&$ others, vegetable and fruit vendors work from 17 to 21 hours respectively on average. Majority of tea, vegetable and fruit street vendors (around 80 per cent) are running these businesses on the basis of primary occupation.

6.

\subsection{Problems Encountered by the Street Vendors}

A lack of capital is the main hindrance in setting up the vending business. In the absence of adequate and sufficient source of fund, vendors are unable to maintain the level of stock and in this process they lose customers and are also unable to meet their own daily needs. The owners of the small businesses are often also might be discouraged to borrow since they know their future stream of income might be lower than their assets (collateral). These businesses also suffer from inefficient managerial skill, lacking risk assurance and 
transportation problem. They failed to obtain loan from established formal financial institutions due to their failure to meet the obligations to manage the collateral. Therefore, we have found in our survey that a small percentage on average $6 \%$ for vegetable and fruit vendors of the owners of small businesses start their businesses by borrowing from the local money lenders at a comparatively higher interest rates. Adverse economic situation negatively affects street vending business.. We have to stop unnecessary eviction for sake of the beautification of the city. If eviction becomes unavoidable government need to suggest an alternative place for the street vendors before eviction takes place. Due to inclement weather, strike majority of the vendors of Dhaka city are reported to have suffered a loss in their income. Consequently, these businesses also suffer from inefficient managerial skill, lacking risk assurance and transportation problem. If transportation system is disrupted, fuel prices is increased, power outages can have adverse affect on the business. They become victim of harassments by officials especially the polices, extortionists, arrests and bribes. They also suffer from poor infrastructural arrangement Majority of the respondents $(62 \%)$ reply that lack of the storage problem forced them to waste their products because they are left with excess of stock at the end of the day.

On the other hand $20 \%$ of them are reported to have received bonus on selling cigarettes. If vendors can submit a larger number of empty packets of cigarette they would get bonus. Once people get accustomed and experience progress and monetary benefit in their businesses they restrain themselves from crime, smuggling, non-market activities \& other unsocial activities.

\subsection{Conclusion and Policy Implications}

- National urban planning should be integrated with street vending businesses' needs and regulations. Participatory approaches can be potentially useful in the successful empowerment of the street vendors of informal sector of Bangladesh. Moreover, we have to accept the right to vend as a part of civil right. Furthermore, we have to protect the usual natural markets where vendors and customers have interacted for a long time. The government of Bangladesh needs to implement a national law on street trade which would clearly uphold the rights of the vendors.

- Through the representation of municipalities, vendors and hawkers association,NGOs and cooperatives they can express their needs, problems and inform government about the deprivation of any of their civil rights. In this way they can incorporate themselves in national policy consultation process.

- The street vendors are usually educated at the secondary level according to our field study which is not a disappointing picture. But what is more important is to make the vendors more educated since higher education can develop their sense of doing business in a better way by managing and improving their source of capital, increasing the level of investment, maintaining proper hygiene and more importantly improving their attitude and behavior with the customers thereby securing a sufficient amount of customers which is known as social capital making their business less vulnerable in the face of natural calamity,political instability or financial crisis. Since hundred percent of the respondents of the sample are the only earning member of their families, necessary steps should be taken to ensure certain level of income.

- It is expected that the government to assist themselves either financially or can help boost the infrastructural development so that their business is uninterrupted. This can be done only if the government gives more attention and spend money to redesign the Dhaka city with the help of modern urban planners where the vendors will not sit on footpath, pavement or in front of railway stations or on road and jeopardize the communication and transportation process.

- In addition, as a result of transient nature and small scale of the informal activity authentic, disaggregated information on time is required to locate these type of businesses with the help of Government to ensure appropriate development of skills through capacity-building activities and financial assistance as required.

- The government should come forward to create, enact and enforce legislation for the street food vendor practices, their working conditions and food handling in close association with consumer participations.

- Proper supply of water, sanitation and waste management services in the natural markets should be engaged by local waste collectors and municipal personnel should be engaged in the management of services. Special markets can be allowed for women vendors.

- As storage is one of the major problems encountered by the street vendors, government can take proper initiative to create storage or can give monetary incentive to the vendors to maintain proper storage to minimize the loss. On the other hand, NGOs can take necessary steps to help the vendors in this regard.

To conclude, this paper is an attempt to add to the existing literature on the informal sector of Bangladesh economy and reveals information often neglected, unrecorded and unrecognized. Bangladesh is yet to emphasize 
the policies on growth of the informal sector partly due to the non-recognition of activities of the informal sector. The goal was to bring into spot light the significance of the informal sector on the development of the economy of Bangladesh. Since street vendors contribute to the urban economy of Bangladesh as customers, distributers of goods, generators of jobs and provide services to the public proper and the size of the informal sector is expanding day by day as the contribution of agriculture to GDP is decreasing and due to massive migration from rural area to urban area, proper emphasis \& attention should be given to the informal sector's role in the development policy of Bangladesh.

\section{Acknowledgements}

We are grateful to the students of department of economics of Southeast University, Dhaka, Bangladesh for their support and enthusiastic cooperation during the process of data collection. We remain also grateful to Dr. Talukder Golam Rabby, Assistant professor, department of economics, Southeast University for his valuable suggestions.

\section{References}

Adhikari, D. B. (2011). Income generation in informal sector: A case study of the street vendors of Kathmondu metropoliton city. Economic Journal of Development Issues, 13\&14(1-2). Combined Issue. Retrieved from http://www.nepjol.info/index.php/EJDI/article/viewFile/7193/5822

Ahuja, R. (2011). Research Methods. Rawat Publications: New Delhi. Retrieved from http://www.mu.ac.in/law/ Select\%20R\%20M\%20Books\%20Dr\%20V\%20Patkar\%201\%20Mar\%202014.pdf

Amin, A. T. M. N. (1989). Dhaka: Past, Present, Future. The Asiatic Society of Bangladesh, Dhaka, Bangladesh.

Andringa \& Kies. (1989), Street food hawkers in Southeast Asia. Utrecht. Wageningen: Agricultural University Wageningen, Netherlands.

Basumatary, R. (2013). Socio Economic Status of Women Vendors in Towns of Kokrajhar District. The Echo An Online Journal of Humanities \& Social Science. Retrieved from https://www.thecho.in/files/socioeconomic-status-of-women-vendors-in-towns-of-kokrajhar-district.pdf

Becker, K. F. (2004). Fact finding study. sida, March 2004, info@sida.se, www.sida.se

Bhowmik, S. K. (2005). Street Vendors in Asia: A Review. Economic and Political Weekly, May 28-June 4 2256-2264.

Chopra, C. (2004). d.o. no.n-11028/2/2002-upa-iii (Vol. V) National Policy for Urban Street Vendors. Government of india, ministry of urban employment, and poverty alleviation (nirman bhavan, new delhi-110001).

Dhemba, J. (1999). Informal sector Development: A strategy for alleviating Urban poverty in Zimbabwe. Journal of Social Development in Africa, 14(2), 5-19. Retrieved from http://archive.lib.msu.edu/DMC/ African\%20Journals/pdfs/social\%20development/vol14no2/jsda014002002.pdf

Faruque, Q., \& Haque, Q. F. (2010). Institutionalization of Healthy Street Food System in Bangladesh: A Pilot Study with Three Wards of Dhaka City Corporation as a Model. National Food Policy Capacity Strengthening Programme (NFPCSP). Final Report PR\#7/07, Dhaka, Bangladesh.

Gottdiener, M., \& Budd, L. (2005). Key Concepts in Urban Studies. Sage Publication, Thousand Oaks and India. http://dx.doi.org/10.4135/9781446279120

Indira, K. (2014). A Study of Street Vending Across the Globe. International Journal of Advanced Research in Computer Science and Software Engineering, 4(9). Retrieved from http://www.ijarcsse.com/docs/papers/ Volume_4/9_September2014/V4I9-0256.pdf

Informal Economy Monitoring Study: Ahmedabad street vendors: Realities and Recommendations. (2008) Retrieved from http://wiego.org/sites/wiego.org/files/publications/files/IEMS-Ahmedabad-Street-VendorsPolicy-Recommendations-English.pdf

Informal Economy Monitoring Study: Nakuru's street vendors: Realities and Recommendations. (2012). Retrieved from http://www.inclusivecities.org/wp-content/uploads/2014/02/IEMS-Nakuru-City-Report-SVenglish.pdf

International Labour Organization and WIEGO. (2013). Women and Men in the Informal Economy: A Statistical Picture (2nd ed.). Retrieved from http://wiego.org/publications/women-and-men-informal-economystatistical-picture-2nd-edition 
Karthikeyan, R., \& Mangaleswaran, R. (2013). Quality of Life among Street Vendors in Tiruchirappalli City, Tamil Nadu, India. International Research Journal of Social Sciences, 2(12), 18-28. Retrieved from http://www.isca.in/IJSS/Archive/v2/i12/4.ISCA-IRJSS-2013-167.pdf

Khanam, M. (2008). Gender inequality: the earning gap between men and women street vendors in dhaka city. Journal of the Asiatic Society of Bangladesh (Humanities), 53(2), 287-303.

Mahmud, Parvez, Hilton, Kabir, \& Wahid. (2014). The role of training in reducing poverty: the case of agricultural workers receiving microcredit in Bangladesh. International Journal of Training and Development, 18(4), 282-290. http://dx.doi.org/10.1111/ijtd.12039

Muinde, O. K., \& Kuria, E. (2005). Hygienic and sanitary practices of vendors of street foods in Nairobi, Kenya. African Journal of Food Agriculture Nutrition and Development. Retrieved from http://www.bioline.org.br/ pdf?nd05012

Murthy, M. N. (1967). Sampling: Theory and Methods. Statistical Publishing Society. Retrieved from http://www.sciepub.com/reference/75519

Muzaffar, A. T., Huq, I., \& Mallik, B. A. (2009). Entrepreneurs of the Streets: an Analytical Work on the Street Food Vendors of Dhaka City. International Journal of Business and Management, 4(2). http://dx.doi.org/10. 5539/ijbm.v4n2p80

National policy on urban street vendors. (2009). Government of India, Ministry of Housing \& Urban Poverty Alleviation. Retrieved from http://mhupa.gov.in/policies/StreetPolicy09.pdf

Nicolo, G. F., \& Bendech, M. A. (2012). Street Food Vending in West African Cities. Food and Agricultural Organization Regional office for Africa. Retrieved from http://www.fao.org/fsnforum/sites/default/files/ resources/STREET\%20FOOD\%20VENDING\%20IN\%20WEST\%20AFRICAN\%20COUNTRIESFinalVer sion.pdf

Nirathron, N. (2006). Fighting Poverty from the Street: A Survey of Street Food Vendors in Bangkok. Informal Economy, Poverty and Employment. Thailand Series Number 1.International Labour Office. Retrieved from http://www.ilo.org/wcmsp5/groups/public/---asia/---ro-bangkok/documents/publication/wcms_bk_pb_128_ en.pdf

Njaya, T. (2014). Nature, Operations and Socio-Economic Features of Street Food Entrepreneurs of Harare, Zimbabwe. IOSR Journal of Humanities and Social Science (IOSR-JHSS), 19(4), 49-58. http://dx.doi.org/10. 9790/0837-19434958

Otoo, Fulton, Ibro, \& Lowenberg-DeBoer. (2009). Women Entrepreneurship in West Africa: The Cowpea Street Food Sector in Niger and Ghana. Journal of Developmental Entrepreneurship, 16(1), 37-63. http://dx.doi.org/10.1142/S1084946711001732

Round, J., Williams, C., \& Rodgers, P. (2010). The role of domestic food production in everyday life in post-Soviet union Ukraine. Annals of the association of American Geographers, 100(5), 1197-1211. http://dx.doi.org/10.1080/00045608.2010.520214

Saha, D. (2010). Decent Work for the Street Vendors in Mumbai-A Distant Vision. International Journal of Workplace Rights, 14(2), 229-250. http://dx.doi.org/10.2190/WR.14.2.f

Saha, D. (2011). Working Life of Street Vendors in Mumbai. Indian Journal of Labour Economics, 54(2), 301-325.

Subratty, A. H., Beeharry, P., \& Chan Sun, M. (2004). A survey of hygiene practices among food vendors in rural areas in Mauritius. Nutrition \& Food Science, 34(5). Retrieved from http://www.emeraldinsight. com/doi/abs/10.1108/00346650410560361.

Suraiya, S., \& Noor, F. (2012). An Analysis of Socioeconomic Conditions of Street Vendors: A Study on Dhaka City. Daffodil International University Journal of Business and Economics, 6(1 \& 2).

The informal sector and informal employment in Bangladesh, ADB Country report. (2010). Retrieved from http://www.adb.org/publications/informal-sector-and-informal-employment-bangladesh

Timalsina, K. (2011). An Urban Informal Economy: Livelihood Opportunity to Poor or Challenges for Urban Governance. Global Journal of Human Social Science, 11(2), version 1.0. Retrieved from https://globaljournals.org/GJHSS_Volume11/4-An-Urban-Informal-Economy.pdf

Winkelried, D. (2005). Income distribution and the size of the informal sector. http://dx.doi.org/10.2139/ 
Ssrn. 777144

\section{Copyrights}

Copyright for this article is retained by the author (s), with first publication rights granted to the journal.

This is an open-access article distributed under the terms and conditions of the Creative Commons Attribution license (http://creativecommons.org/licenses/by/3.0/). 